\title{
Pengaruh Pemberian Berbagai Jenis Pupuk Kandang Dan Media Tanam Yang Berbeda Terhadap Pertumbuhan Dan Produksi Tanaman Mentimun (Cucumis sativus L.)
}

\author{
Mustaman $^{1}$, Masdar Fatman ${ }^{2}$ \\ Program Studi Agroteknologi Universitas Al Asyariah Mandar \\ 1tamanknya_indah@yahoo.co.id \\ ${ }^{2}$ masdar_fatman@yahoo.com
}

\begin{abstract}
Abstrak
Pupuk kandang merupakan pupuk yang berasal dari kotoran hewan yang digunakan untuk menyediakan unsur hara bagi tanaman. Pupuk kandang berperan untuk memperbaiki sifat fisik, kimia, dan biologi tanah. Komposisi unsure hara yang terdapat pada pupuk kandang sangat tergantung jenis hewan, alas kandang dan pakan yang diberikan pada hewan tersebut. Penelitian ini bertujuan untuk mengetahui respon pemberian pupuk kandang dan media tanam yang berbeda terhadap pertumbuhan dan produksi tanaman mentimun.Penelitian ini menggunakan rancangan acak kelompok RAK dalam bentuk faktorial. Pemberian pupuk kandang berbeda ( $\mathrm{K}$ ) sebagai faktor pertama yang terdiri dari 3 taraf yaitu : K1: pupuk kandang ayam 200 gram/tanaman, K2: pupuk kandang kambing 200 gram/tanaman, K3: pupuk kandang sapi 200 gram/tanaman. Sedangkan media tanam yang berbeda ( T ) sebagai faktor kedua yang terdiri dari 3 taraf yaitu : T1: media tanam menggunakan arang sekam, T2: media tanam menggunakan serbuk gergaji, T3 : media tanam menggunakkan pasir. Sehingga terdapat 9 kombinasi perlakuan setiap perlakuan menggunakan 2 tanaman sehingga diperoleh 18 kombinasi perlakuan, dengan masing-masing 2 tanaman per perlakuan sehingga diperoleh 54 jumlah tanaman. Hasil penelitian menunjukkan bahwa Pemberian berbagai jenis pupuk kandang $(\mathrm{K})$ tidak memberikan pengaruh baik terhadap parameter waktu muncul tunas, tinggi tanaman, umur berbunga, jumlah buah, panjang buah, dan berat buah. Penggunaan media tanam yang berbeda (T) memberikan pengaruh baik terhadap parameter waktu muncul tunas, tinggi tanaman, umur berbunga, jumlah buah, panjang buah, dan parameter berat buah.
\end{abstract}

Kata Kunci : Pupuk Kandang, Mentimun, Media Tanam

\section{PENDAHULUAN}

Indonesia merupakan negara yang subur dan kaya akan hasil pertanian dan perkebunan. Potensi yang ada tersebut dapat menjadi sumber pendapatan bagi masyarakat Indonesia. Banyak masyarakat Indonesia yang menjadikan sektor pertanian menjadi sumber mata pencaharian. Selain itu juga sektor pertanian ini dapat menyediakan pasar dan bahan baku untuk produksi bagi sektor industri dan menghasilkan devisa yang dapat digunakan untuk pembangunan (Arlina 2015).

Mentimun adalah salah satu sayuran buah yang banyak di konsumsi segar oleh masyarakat Indonesia. Meskipun bukan tanaman Indonesia, tetapi mentimun sudah sangat di kenal oleh masyarakat Indonesia. Jenis sayuran ini dengan mudah ditemukan hampir seluruh pelosok Indonesia. Mentimun juga dikenal dalam dunia kesehatan sebagai obat batuk, penurunan panas dalam, bahkan mentimun yang dikukus dan di simpan sehari semalam lalu di diamkan langsung akan berkhasiat mengurangi sakit tenggorokan dan batuk-batuk.
Dalam proses pengembangan tanaman mentimun sering mengalami kendala, terutama dalam hal sifat fisik dan kimia tanah. Tanah yang kurang subur menyebabkan produksi menurun. Untuk itu dalam penanaman mutlak diperlukan pengolahan tanah dan penambahan unsur hara. Dalam hal ini dapat dilakukan pemanfaatan pupuk kandang dan pemupupukan anorganik sebagai solusi yang dapat dilakukan (Fajar yuyanto 2013).

Produksi tentang mentimun di Indonesia sesuai data BPS (2008) masih rendah yaitu 3,5 ton/ha sampai 4,8 ton/ha, padahal produksi mentimun hibrida bisa mencapai 20 ton/ha. Budidaya tanaman mentimun dalam skala produksi yang tinggi dan intensif belum banyak dilakukan, pada umumnya tanaman mentimun ditanam sebagai tanaman selingan (Arlina 2015).

\section{BAHAN DAN METODE}

Penelitian ini dilaksanakan pada bulan Agustus sampai bulan November Tahun 2016 di 
Desa Mekkatta Kecamatan Malunda Kabupaten Majene Provinsi sulawesi Barat. Penelitian menggunakan Rancangan Acak Kelompok (RAK) dengan pola faktorial. yang terdiri dari 2 ( dua ) faktor yaitu : Pertama yaitu Pupuk Kandang Yang Berbeda( $\mathrm{K}$ ) terdiri dari 3 taraf yaitu K1: pupuk kandang ayam K2: pupuk kandang kambing K3 pupuk kandang sapi masing masing $200 \mathrm{~g} /$ tanaman Faktor kedua adalah Media Tanam ( $\mathrm{T}$ ) dengan 3 taraf perlakuan yaitu T1: Media Tanam Menggunakan arang sekam + Tanah, T2 :Media Tanam Menggunakan serbuk gergaji + Tanah dan T3: Media tanam menggunakan pasir + Tanah

Setiap perlakuan diulang sebanyak 3 kali, sehingga terdapat 27 unit penelitian setiap unit penelitian menggunakan 2 tanaman, sehingga jumlah tanaman seluruhnya 54 tanaman.

\section{HASIL DAN PEMBAHASAN}

Waktu Muncul Tunas ( hari )

Sidik ragam menunjukkan bahwa pemberian pupuk kandang berbeda ( $\mathrm{K}$ ) dan interaksinya ( $\mathrm{K}$ x T) tidak memberikan pengaruh nyata. Sedangkan media tanam berbeda ( $\mathrm{T}$ ) memberikan pengaruh sangat nyata terhadap waktu muncul tunas.

Tabel 1. Rata-Rata Waktu Muncul Tunas (Hari) Pada Pemberian Berbagai Pupuk Kandang Yang Berbeda Dengan Penggunaan Media Tanam Yang Berbeda

\begin{tabular}{ccccc}
\hline Pupuk & \multicolumn{3}{c}{ Media Tanam Berbeda } & \\
\cline { 2 - 4 } $\begin{array}{c}\text { Kandang } \\
\text { Berbeda }\end{array}$ & $\mathrm{T} 1$ & $\mathrm{~T} 2$ & $\mathrm{~T} 3$ & \\
\hline $\mathrm{K} 1$ & 3,67 & 3,00 & 3,00 & 3,22 \\
$\mathrm{~K} 2$ & 3,33 & 3,00 & 3,00 & 3,11 \\
$\mathrm{~K} 3$ & 3,67 & 3,33 & 3,00 & 3,33 \\
\hline Rata-rata & $3,55^{\mathrm{bc}}$ & $3,11^{\mathrm{a}}$ & $3,00^{\mathrm{a}}$ & \\
\hline $\begin{array}{c}\text { NP.UJBD } \\
\text { Taraf } \alpha\end{array}$ & 0,38 & 0,37 & & \\
0,05 & & & & \\
\hline
\end{tabular}

Keterangan : angka yang diikuti oleh huruf yang tidak sama berarti berbeda nyata pada uji jarak berganda duncan taraf $\alpha 0,05$

Hasil analisis statistik Uji Jarak berganda duncan taraf $\alpha 0,05$ pada tabel 1 menunjukkan bahwa penggunaan media tanam menggunakan Pasir ( T3 ) memberikan pengaruh lebih baik dan berbeda sangat nyata dibandingkan dengan media tanam menggunakan Arang Sekam ( T1 ) dan Media tanam menggunakan Serbuk Gergaji ( T2). Hal ini diduga karena kandungan unsur hara makro yang terkandung dalam media tanam pasir yang mampu mempercepat waktu munculnya tuas, hal ini sesuai yang dikutib dalam blok (Tanaman advertisemen 2015) Bahwa Media tanam bertekstur pasir sangat mudah diolah, tanah jenis ini memiliki aerasi (ketersediaan rongga udara) dan drainase yang baik. Pasir mengandung unsur hara phospor (0,08 g), kalsium (2,53 g), $\mathrm{Fe}_{2} \mathrm{O}_{3}(5,19 \mathrm{~g})$ dan $\mathrm{MgO}(1,02 \mathrm{~g})$ (Anonim, 2015).

\section{Tinggi tanaman ( $\mathrm{cm}$ )}

Sidik ragam menunjukkan bahwa pemberian pupuk kandang berbeda ( $\mathrm{K}$ ) dan interaksinya $(\mathrm{K} \times \mathrm{T})$ tidak memberikan pengaruh nyata. Sedangkan media tanam berbeda ( $\mathrm{T}$ ) memberikan pengaruh sangat nyata terhadap Tinggi Tanaman.

Tabel 2. Rata-Rata Tinggi Tanaman (Cm) Pada Pemberian Berbagai Pupuk Kandang Yang Berbeda Dengan Penggunaan Media Tanam Yang Berbeda

\begin{tabular}{|c|c|c|c|c|}
\hline \multirow{2}{*}{$\begin{array}{c}\text { Pupuk } \\
\text { Kandang } \\
\text { Berbeda }\end{array}$} & \multicolumn{3}{|c|}{ Media Tanam Berbeda } & \multirow{2}{*}{$\begin{array}{l}\text { Rata- } \\
\text { Rata }\end{array}$} \\
\hline & $\mathrm{T} 1$ & $\mathrm{~T} 2$ & $\mathrm{~T} 3$ & \\
\hline K1 & 130,93 & 147,83 & 148,13 & 142,29 \\
\hline K2 & 129,52 & 146,62 & 16,07 & 140,73 \\
\hline K3 & 131,68 & 147,65 & 146,93 & 142,08 \\
\hline Rata-rata & $130,71^{\mathrm{a}}$ & $147,36^{\mathrm{b}}$ & $147,03^{\mathrm{a}}$ & \\
\hline $\begin{array}{c}\text { NP.UJBD } \\
\text { Taraf } \alpha \\
0,01\end{array}$ & 3,26 & 3,42 & & \\
\hline
\end{tabular}

Keterangan : angka yang diikuti oleh huruf yang tidak sama berarti berbeda nyata pada uji jarak berganda duncan taraf $\alpha 0$,

Hasil analisis statistik Uji Jarak berganda duncan taraf $\alpha 0,01$ pada tabel 2 menunjukkan bahwa penggunaan media tanam menggunakan Serbuk Gergaji ( T2 ) memberikan pengaruh lebih baik dan berbeda sangat nyata dibandingkan dengan Media tanam menggunakan arang sekam ( T1 ) dan menggunakan Pasir (T3). Hal ini diduga karena kandungan unsur hara Nitrogen 0,04-0,10 \% yang terkandung dalam media tanam serbuk gergaji yang mampu meningkatkan pertumbuhan tanaman, Nitrogen Berfungsi sebagai Pembentukan atau pertumbuhan bagian vegetatif tanaman, seperti daun, batang, dan akar. Kemudian berperang penting dalam hal pembentukan hijau daun yang berguna sekali dalam proses fotosinesis dan membentuk protein, lemak, dan berbagai persenyawaan organik (Anonom 2015).

\section{Umur Berbunga ( hari )}

Sidik ragam menunjukkan bahwa pemberian pupuk kandang berbeda ( $K$ ) dan

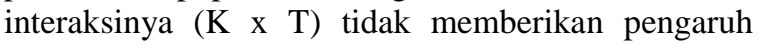


nyata. Sedangkan media tanam berbeda ( $\mathrm{T}$ ) memberikan pengaruh sangat nyata terhadap Umur Berbunga.

Tabel 3.Rata-Rata Umur Berbunga (Hari) Pada Pemberian Berbagai Pupuk Kandang Yang Berbeda Dengan Penggunaan Media Tanam Yang Berbeda

\begin{tabular}{ccccc}
\hline $\begin{array}{c}\text { Pupuk } \\
\text { Kandang } \\
\text { Berbeda }\end{array}$ & \multicolumn{2}{c}{ Media Tanam Berbeda } & $\begin{array}{c}\text { Rata- } \\
\text { Rata }\end{array}$ \\
\cline { 2 - 4 } K1 & 26,33 & 25,67 & 25,33 & 25,77 \\
K2 & 26,67 & 25,67 & 25,00 & 25,78 \\
K3 & 26,67 & 26,33 & 25,00 & 26,00 \\
\hline Rata-rata & $26,56^{\text {bc }}$ & $25,89^{\text {ab }}$ & $25,11^{\mathrm{a}}$ & \\
\hline $\begin{array}{c}\text { NP.UJBD } \\
\text { Taraf } \alpha \\
0,01\end{array}$ & 0,61 & 0,65 & & \\
\hline
\end{tabular}

Keterangan : angka yang diikuti oleh huruf yang tidak sama berarti berbeda nyata pada uji jarak berganda duncan taraf $\alpha 0,01$

Hasil analisis statistik Uji Jarak berganda duncan taraf $\alpha 0,05$ pada tabel 3 menunjukkan bahwa penggunaan media tanam Menggunakan menggunakan Pasir ( T3 ) memberikan pengaruh lebih baik dan berbeda sangat nyata dibandingkan dengan Media tanam menggunakan serbuk gergaji ( T2 ) dan Media tanam menggunakan arang sekam ( T1). hal ini diduga karena kandungan unsur hara fhosfor ( $0,08 \mathrm{~g})$ yang terkandung dalam media tanam pasir mampu mempercepat proses pembungaan pada tanaman mentimun (Anonim 2015).

\section{Jumlah Buah ( buah )}

Hasil pengamatan Jumlah Buah (buah) dan sidik ragam disajikan pada Tabel lampiran 4a dan 4b. Sidik ragam menunjukkan bahwa pemberian pupuk kandang berbeda $(\mathrm{K})$ dan interaksinya $(\mathrm{K} \times \mathrm{T})$ tidak memberikan pengaruh nyata. Sedangkan media tanam berbeda (T) memberikan pengaruh sangat nyata terhadap Jumlah Buah.

Tabel 4. Rata-Rata Jumlah Buah (buah) pada pemberian berbagai pupuk kandang yang berbeda dengan penggunaan media tanam yang berbeda

\begin{tabular}{ccccc}
\hline $\begin{array}{c}\text { Pupuk } \\
\text { Kandang } \\
\text { Berbeda }\end{array}$ & \multicolumn{2}{c}{ Media Tanam Berbeda } & \multirow{2}{*}{$\begin{array}{c}\text { Rata- } \\
\text { Rata }\end{array}$} \\
\cline { 2 - 4 } K1 & $6,67^{\mathrm{a}}$ & $7,67^{\mathrm{a}}$ & $9,00^{\mathrm{bc}}$ & 7,78 \\
$\mathrm{~K} 2$ & $6,67^{\mathrm{a}}$ & $8,00^{\mathrm{b}}$ & $8,00^{\mathrm{b}}$ & 8,55
\end{tabular}

\begin{tabular}{ccccc}
$\mathrm{K} 3$ & $6,33^{\mathrm{a}}$ & $7,67^{\mathrm{b}}$ & $7,33^{\mathrm{a}}$ & 7,11 \\
\hline Rata-rata & 7,55 & 7,78 & 8,11 & \\
\hline $\begin{array}{c}\text { NP.UJBD } \\
\text { Taraf } \alpha \\
0,01\end{array}$ & 0,86 & 0,91 & & \\
\hline
\end{tabular}

Keterangan : Angka yang diikuti oleh huruf yang tidak sama berarti berbeda nyata pada Uji Jarak berganda duncan taraf $\alpha 0,01$

Hasil analisis statistik Uji Jarak berganda duncan taraf $\alpha 0,01$ pada tabel 4 menunjukkan bahwa penggunaan media tanam Menggunakan Pasir ( T3 ) memberikan pengaruh lebih baik dan berbeda sangat nyata dibandingkan dengan Media tanam menggunakan serbuk gergaji ( T2 ) dan Media tanam menggunakan arang sekam ( T1) terhadap jumlah Buah.

Hal ini diduga karena kandungan fospor (P) yang dimili oleh media tanam Menggunakan pasir yang mampu memacu pembentukan bunga dan buah, bahanpembentuk inti sel dan dinding sel, mendorong pertumbuhan akar muda dan pemasakan biji, pembentukan klorofil pentimg dalam cadangan transfer energi

Berat Buah ( gram )

Sidik ragam menunjukkan bahwa pemberian pupuk kandang berbeda ( $\mathrm{K}$ ) dan interaksinya ( $\mathrm{K}$ x T) tidak memberikan pengaruh nyata. Sedangkan media tanam berbeda ( $\mathrm{T}$ ) memberikan pengaruh sangat nyata terhadap Berat Buah.

Tabel 5. Rata-Rata Berat Buah (gram) pada pemberian berbagai pupuk kandang yang berbeda dengan penggunaan media tanam yang berbeda

\begin{tabular}{ccccc}
\hline Pupuk & \multicolumn{3}{c}{ Media Tanam Berbeda } & \multirow{2}{*}{$\begin{array}{c}\text { Rata- } \\
\text { Kandang }\end{array}$} \\
\cline { 2 - 4 } Berbeda & $\mathrm{T} 1$ & $\mathrm{~T} 2$ & $\mathrm{~T} 3$ & \\
\hline K1 & 346,00 & 365,33 & 363,67 & 358,33 \\
$\mathrm{~K} 2$ & 349,33 & 365,67 & 364,00 & 359,66 \\
K3 & 350,33 & 366,00 & 364,67 & 360,33 \\
\hline Rata-rata & $348,55^{\mathrm{a}}$ & $365,66^{\mathrm{b}}$ & $364,11^{\mathrm{a}}$ & \\
\hline NP.UJBD & & & & \\
Taraf $\alpha$ & 8,17 & 8,59 & & \\
0,01 & & & & \\
\hline
\end{tabular}

Keterangan : angka yang diikuti oleh huruf yang tidak sama berarti berbeda nyata pada uji jarak berganda duncan taraf $\alpha 0,01$

Hasil analisis statistik Uji Jarak berganda duncan taraf $\alpha 0,01$ pada tabel 5 menunjukkan bahwa penggunaan media tanam Menggunakan serbuk gergaji ( T2 ) memberikan pengaruh lebih baik dan berbeda sangat nyata dibandingkan denagan Media 
tanam menggunakan pasir ( T3 ) dan Media tanam menggunakan Arang sekam ( T1 ) terhadap berat Buah.

Menurut Mang Yono (2015) bahwa pada tanaman mentimun setelah berbunga banyak melakukan pembentukan buah yang kenyataanya pada waktuwaktu tersebut diperlukan unsur-unsur atau zat-zat pembentuk yang cukup sesuai dengan kegiatankegiatan pertukaran zatnya yang intensif, dengan kata lain sesuai dengan kegiatan kepentingan berbagai proses fisiologisnya dimana tanaman itu memerlukan unsur hara yang cukup sehungga berdasar kegiatan kepentingannya itu perlu pemupukan (pemberian unsur hara) yang sesuai dengan keperluannya yang dapat diberikan melalui daun atau melalui tanah untuk selanjutnya di absorbsi melalui akar tanaman.

\section{Panjang Buah ( cm )}

Sidik ragam menunjukkan bahwa pemberian pupuk kandang berbeda ( $\mathrm{K}$ ) dan interaksinya ( $\mathrm{K}$ x T) tidak memberikan pengaruh nyata. Sedangkan media tanam berbeda ( $\mathrm{T}$ ) memberikan pengaruh sangat nyata terhadap Panjang Buah. Rata-Rata Panjang Buah $(\mathrm{cm})$ pada pemberian berbagai pupuk kandang yang berbeda dengan penggunaan media tanam yang berbeda terhadap pertumbuhan dan produksi tanaman mentimun.

\begin{tabular}{ccccc}
\hline $\begin{array}{c}\text { Pupuk } \\
\text { Kandang } \\
\text { Berbeda }\end{array}$ & \multicolumn{3}{c}{ Media Tanam Berbeda } & \multirow{2}{*}{$\begin{array}{c}\text { Rata- } \\
\text { Rata }\end{array}$} \\
\cline { 2 - 4 } & $\mathrm{T} 1$ & $\mathrm{~T} 2$ & $\mathrm{~T} 3$ & \\
\hline K1 & 19,33 & 23,33 & 23,67 & 22,11 \\
K2 & 20,00 & 23,33 & 23,00 & 22,11 \\
K3 & 19,00 & 23,00 & 23,00 & 21,66 \\
\hline Rata-rata & $19,44^{\mathrm{a}}$ & $23,22^{\mathrm{b}}$ & $23,22^{\mathrm{b}}$ & \\
\hline NP.UJBD & & & & \\
Taraf $\alpha$ & 0,66 & 0,69 & & \\
0,01 & & & &
\end{tabular}

Keterangan : Angka yang diikuti oleh huruf yang tidak sama berarti berbeda nyata pada Uji Jarak berganda duncan taraf $\alpha 0$,

Hasil analisis statistik Uji Jarak berganda duncan taraf $\alpha 0,05$ pada tabel 6 menunjukkan bahwa penggunaan Media tanam menggunakan serbuk gergaji ( T2 ) dan Media tanam menggunakan pasir ( T3 ) memberikan pengaruh lebih baik dan berbeda sangat nyata dibandingkan dengan penggunaan media tanam Menggunakan arang sekam (T1) terhadap panjang Buah. . Hal ini sesuai dengan pendapat medionovianto (2008), bahwa pupuk organik adalah hasil dari pembusukan bahan-bahan organik yang berasal dari sisa tanaman, kotoran hewan, dan manusia yang mengandung unsur haranya lebih dari satu unsur, kelebihan dari pupuk organik ini adalah dapat secara cepat mengatasi devesiensi hara, tidak bermasalah dalam pencucian hara dan mampu menyediakan hara secara cepat namun lambat dalam proses absorpsim atau penyerapannya pada tanaman dalam hal ini proses awalnya lebih pada perbaikan media tumbuh tanah.

\section{KESIMPULAN}

Berdasarkan hasil penelitian yang telah dilakukan maka dapat disimpulkan bahwa :

Interaksi antara pemberian berbagai jenis pupuk kandang dan media tanam yang berbeda tidak memberikan pengaruh nyata terhadap parameter waktu muncul tunas, tinggi tanaman, umur berbunga, jumlah buah, panjang buah, dan berat buah. Pemberian berbagai jenis pupuk kandang ( $\mathrm{K}$ ) tidak memberikan pengaruh nyata terhadap parameter waktu muncul tunas, tinggi tanaman, umur berbunga, jumlah buah, panjang buah, dan berat buah. Penggunaan media tanam yang berbeda ( $T$ ) memberikan hasil terbaik terhadap parameter waktu muncul tunas, tinggi tanaman, umur berbunga, jumlah buah, panjang buah, dan berat buah.

\section{DAFTAR PUSTAKA}

Alamtani,2013 pupuk kandang http: alamtani.com/pupuk kandang.html

Arlina 2015, Mengenal karakteristik dan syarat tumbuh.html w.w.w. Petani hebat.com/2015/10/klasifikasasi dan morfologi tanaman timun.html

Cecep risnandar. Pemberian pupuk kandang. http//www.academiedu. diakses 21 juni 2016.

Fajar Yulyanyo, 2013 Karakteristik Tanaman Mentimun

http//anakindonesia95.blogspot.co.id/2013/0

9/faktor-faktor-yang mempeng aruhi.html Diakss hari senin 07 februari 2017 jam $16: 34$

Ibu tani 2011, Asal usul Tanaman Mentimun repository.usu.ac.id/bitstream/123456789/2 0895/2/Reference.pdf

Nangiman,2014,http://www.nangimam.com/2014/02/ manfaat-kotoran-ayam-sebagai-pupuk.html

Sumpena, U. 2001. Budidaya Mentimun Intensif dengan Mulsa Secara Tumpang Gilir. Penebar Swadaya. Jakarta. Hal, 1-46

Sutanto, 2002. Penerapan Pertanian Organik, bungamasamba.blogspot.com/2010/10/maka lah-biologi.htm

Tanaman advertisement, 2015. http//www.tipsberkebun.com// jenis-jenis media tanam. Diakses 20 juni jam 13:17 
Repository.usu.ac.id/bitstream/12repository.usu.ac.id /bitstream/123456789/28859/2/Reference.pd $f$

Mang Yono, 2015. Ciri ciri Tanaman Mentimun

https://www.mangyono.com/2015/07/ciri-ciritanaman-mentimun.html

Medionovianto, D. 2008. Membuat Pupuk Kompos dari Kotoran Sapi. Tabloid Sinar Tani. Jakarta. Diposkan oleh Hidayattullah di
05.37

12/Refpupukorganiklampung.blogspot.com/2 013_09_01_archive.html

Media neliti, 2013 Manfaat penambahan arang sekam

https://media.neliti.com/media/publications/58740ID-pengaruh-penambahan-arang-dan-abusekam.pdf. 